Chirurgia (2019) 114: 401-408

No. 3, May - June

Copyright@ Celsius

http://dx.doi.org/10.21614/chirurgia.114.3.401

\title{
The Role of Histopathology and Immunohistochemistry in the Diagnosis of Neuroendocrine Biliary Duct Tumor
}

\author{
Mirela Patricia Sîrbu Boeți ${ }^{1,2}$, Andrei Marius Baicu', Nicolae Bacalbașa ${ }^{1,2}$, Ioana Lupescu ${ }^{1,2}$, Mirela Boroș ${ }^{2}$, \\ Vlad Herlea², Ioana Niculina Luca'2 ${ }^{2}$ Vladislav Brașoveanu ${ }^{2}$
}

${ }^{1}$ Carol Davila University of Medicine and Pharmacy, Bucharest, Romania

${ }^{2}$ Fundeni Clinical Institute, Bucharest, Romania

Corresponding author:

Mirela Patricia Sîrbu Boeți, MD

Fundeni Clinical Institute, 258

Fundeni Street, Bucharest, district 2

Romania

E-mail: paboet@yahoo.com
Received: 02.07.2018 Accepted: 09.09.2018

\section{Rezumat \\ Rolul histopatologiei și imunohistochimiei în diagnosticul tumorii neuroendocrine de duct biliar}

Tumorile neuroendocrine ale tractului biliar sunt entități rare, dezvoltate din celulele Kulchitsky, care suferă un proces de transformare neoplazică. $\mathrm{Cu}$ toate acestea, diagnosticul diferențial dintre tumorile neuroendocrine de tract biliar şi colangiocarcinomul hilar este foarte dificil de stabilit preoperator; prin urmare, majoritatea pacienților sunt supuşi intervenției chirurgicale cu viză de radicalitate, iar diagnosticul definitiv rămâne să fie confirmat de studiile histopatologice şi imunohistochimice ale piesei de rezecție. Prezentăm cazul unei paciente în vârstă de 60 de ani, care a fost supusă unei interventii chirurgicale complexe, ce a constat în hepatectomie dreaptă extinsă (incluzând segmentul IV şi lobul caudat), în bloc cu rezecția căilor biliare extrahepatice şi conservarea canalului hepatic stâng, colangiojejunostomie stângă (tehnica Roux-En-Y), limfadenectomia ganglionilor adiacenți arterei hepatice comune şi trunchiului celiac şi rezecția segmentară a venei porte cu anastomoză termino-terminală, pentru o tumoră la nivelul carrefour-ului biliar, extinsă pe ductul hepatic drept şi invazivă în vena portă. Studiile histopatologice şi imunohistochimice au confirmat prezența unei tumori neuroendocrine de gradul 1, aceasta fiind pozitivă pentru Cromogranina A, Enolaza Neuron Specifică (NSE) şi Ki-67 (1\% pozitivă nuclear). La 24 luni postoperator, pacienta este lipsită de recurențe tumorale. 
Cuvinte cheie: tumoră neuroendocrină de duct biliar, rezecție hepatică, hepatectomie dreaptă extinsă, rezecție de venă portă, imunohistochimie

\section{Abstract}

Neuroendocrine tumors of the biliary tract are rare entities developed form Kulchitsky cells which undergo a process of malignant transformation. However, the differential diagnostic between neuroendocrine tumors of the biliary tract and hilar cholangiocarcinoma is very difficult to be established during the preoperative workup; therefore, most patients are submitted to surgery with radical intent and the final diagnostic remains to be confirmed through histopathological and immunohistochemistry studies of the specimen of resection. We present the case of a 60 year old patient who was submitted to en bloc extended right hepatectomy (including segment IV and caudate lobe) with extra hepatic biliary tree resection and left hepatic duct preservation, left cholangiojejunostomy (Roux-En-Y technique), celiac and common hepatic arteries lymphadenectomy and segmental portal vein resection with end-to-end anastomosis for a tumor of the biliary carrefour extended to the right biliary duct and invading the portal vein. The histopathological and immunohistochemistry studies confirmed the presence of a grade 1 neuroendocrine tumor, the staining being positive for Chromogranin A, Neuron-Specific Enolase (NSE) and Ki-67 (1\% nuclear positive). At 24 months follow-up the patient is free of recurrent disease.

Key words: neuroendocrine biliary duct tumor, hepatic resection, right extended hepatectomy, portal vein resection, immunohistochemistry

\section{Introduction}

Neuroendocrine tumors (NETs) are benign or malignant histopathological entities, secretory or non-secretory, developed in one organic structure (pancreas, ileum, liver, lung etc.) or more (carcinoids). These are slow growing tumors, difficult to diagnose in early stages. NETs represent a small fraction (approximately 3\%) of all neoplasms and their occurrence is influenced by genetic mutations. These tumors are found mostly in the digestive system $(54.5 \%)$, but their incidence is low at the biliary tree level (0.5$2 \%$ ) being sometimes preoperative and even intraoperative misdiagnosed as hilar cholangiocarcinoma (Klatskin tumors). In the following clinical case, there are highlighted the difficulty of diagnosiing a non-secretory NET at the biliary tract level, need for a complex surgical resection and role of histopathological and immunohisto- chemistry examinations in the oncological management.

\section{Case Report}

P.D., a 60-year-old woman, was admitted in our department on 23 May 2013 for mild obstructive jaundice and upper abdominal pain lasting for 3 weeks. The patient underwent laparoscopic cholecystectomy in 2004 for chronic cholecystitis. She denies any drug allergy or chronic medication regimen. The local examination revealed epigastric pain with no muscular contraction, no signs of neither ascites nor palpable mass. The patient's blood tests revealed elevated levels of AST (144 U/L), total bilirubin $(2.7 \mathrm{mg} / \mathrm{dL})$, lipase $(62 \mathrm{U} / \mathrm{L})$ and fibrinogen $(481.3 \mathrm{mg} / \mathrm{dL})$. The MRI examination of the abdomen showed dilated intrahepatic biliary ducts, dilated right branch of portal vein, hypo perfusion in the right hepatic lobe (VII and 
VIII segments) and obstruction at the level of the convergence of the two hepatic ducts, extending to the right hepatic duct (Figs. 1,2). To define the cause of the biliary tree obstruction, immunologic test were requested, and the results showed normal AFP and CEA, but a raised CA19-9 value ( $>400 \mathrm{U} / \mathrm{mL})$.

Based on the clinical and paraclinical exams, the patient was suspected of hilar cholangiocarcinoma, type IIIa on Bismuth Corlette classification.

Intraoperatively a mass was found comprising the primary and the right secondary biliary confluence, along with the involvement of the portal vein (close to its bifurcation). It was decided and performed en bloc extended right hepatectomy (including segment IV and caudate lobe) with extra hepatic biliary tree resection and left hepatic duct preservation, left cholangiojejunostomy (Roux-En-Y technique) for the restoration of the biliary flow, celiac and common hepatic arteries lymphadenectomy and segmental portal vein resection with end-to-end anastomosis. All the surgical procedures were performed successfully.

On histopathological (HP) examination, there were no hepatic or lymphatic metastases. The tumor was $25 / 10 \mathrm{~mm}$ in size and composed of small cells with $1 / 10$ high power fields mitoses. The HP diagnosis was of neuroendocrine tumor, completed by immunohistochemistry tests (Figs. 3, 4).

Specific neuroendocrine tumor markers

Figure 1. Biliary obstruction due to a tumoral nodule (white arrow) which infiltrates the common hepatic duct, the central part of the right and the left hepatic ducts, with moderate intrahepatic biliary tree obstruction (black arrow) - MRI evaluation in axial T2wi and T1wi after Gd i.v. injection in axial plane.

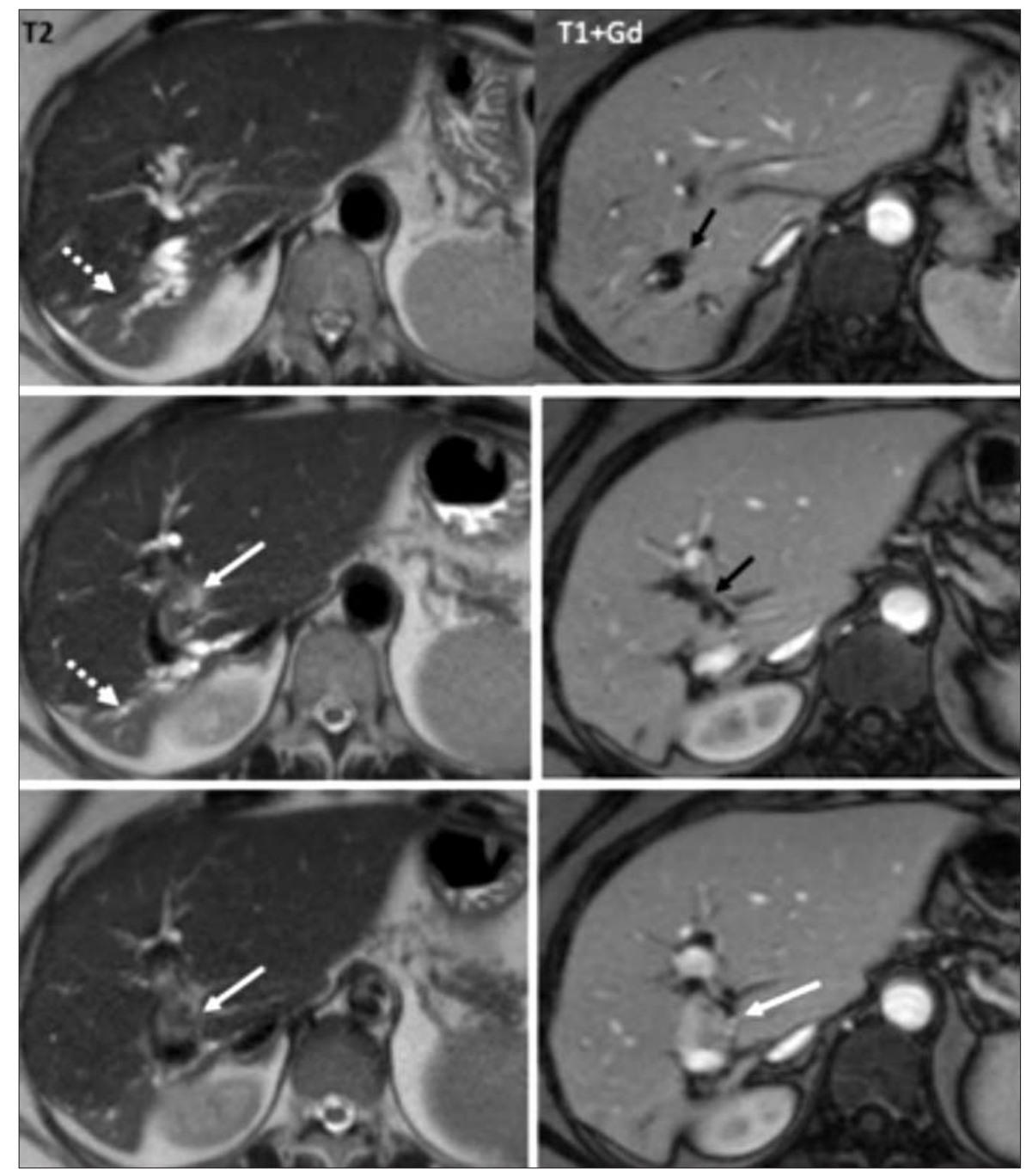


Figure 2. For surgery planning the $\mathrm{T} 1 \mathrm{Gd}$ enhancement acquisition in coronal plane and the MRCP acquisition are very useful to evaluate the complete extension of the tumor (white arrow) and the aspect of the biliary tree (black arrow). Note also the inflammatory changes into the liver parenchyma adjacent to the dilated intrahepatic biliary ducts (dashed arrow).

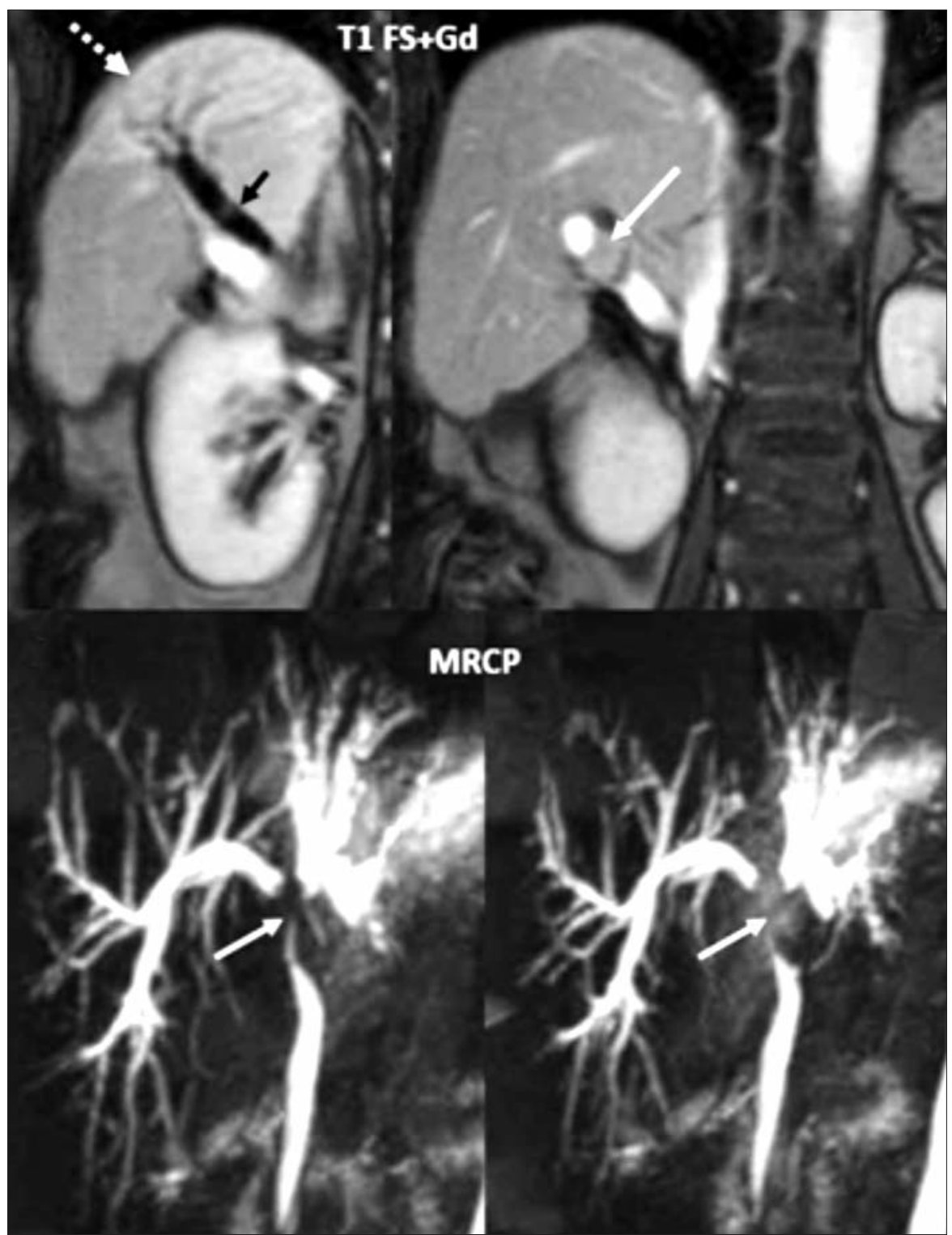

Figure 3. HP examination, using Hematoxylin and eosin stain at 10x magnification.

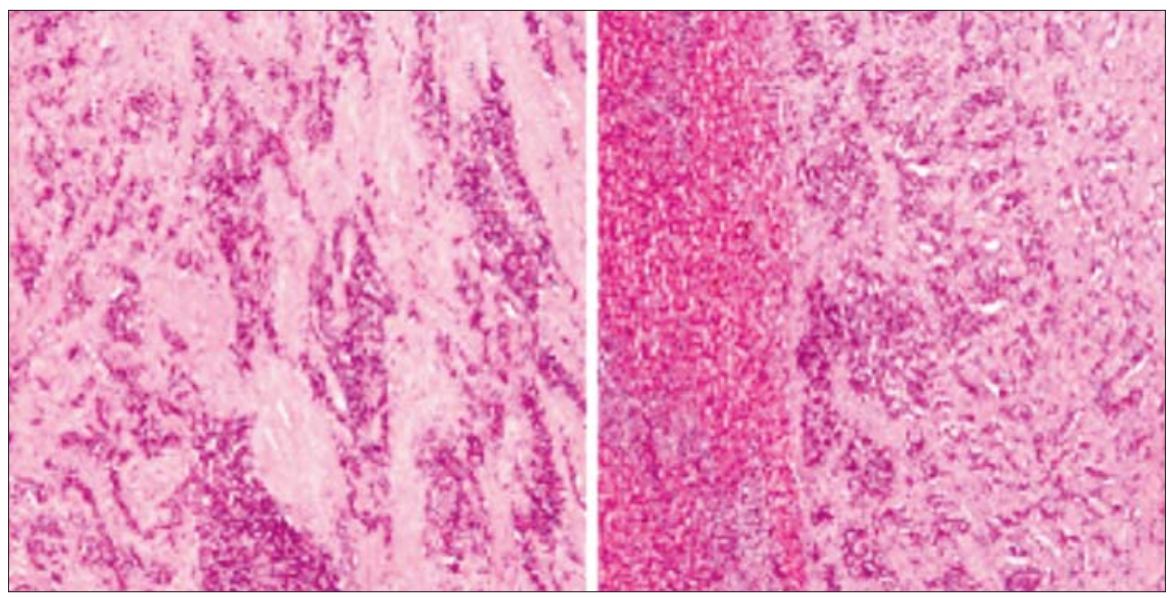


Figure 4. IHC test, using Chromogranin A (left), Ki-67 (centre) and Neuron-SpecificEnolase (right). 10x magnification.

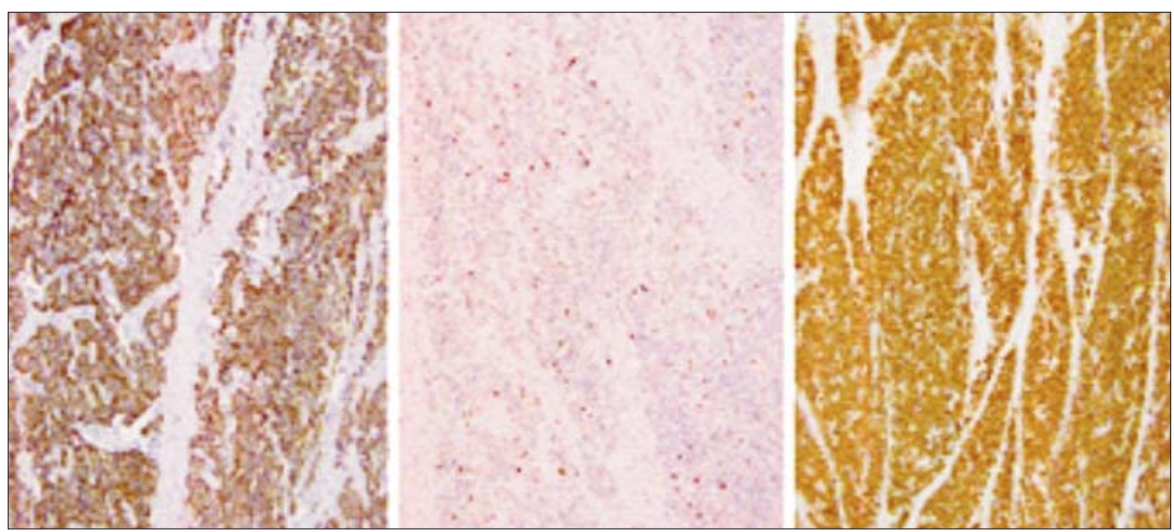

were determined and the tumor was positive for Chromogranin A, Neuron-Specific Enolase (NSE) and Ki-67 (1\% nuclear positive). The IHC aspect supports the HP diagnosis and based on the World Health Organization (WHO) grading system from 2010 (1) for neuroendocrine tumors it received Grade 1 $(<2 / 10 \mathrm{HPF}$ and $<2 \% \mathrm{Ki}-67)$.

Postoperatively the patient's evolution was free of complications and she was discharged from the hospital after 5 days. Oncological treatment was not indicated based on the tumoral type, size and grade. The patient was lost to oncological follow-up on 2015, 24 months after surgery, being disease-free on the MRI evaluation (Fig. 5).

\section{Patient Consent}

The patient provided written informed consent and gave permission for the use of biopsies and publication of her case details.

\section{Discussion}

Neuroendocrine tumors usually originate from Kulchitsky cells of the gastro-enteropancreatic tract which undergo a premalig-

Figure 5. Postoperative abdominal MRI evaluation: fibrotic changes (white arrow) in the adjacent area of surgical liver resection.

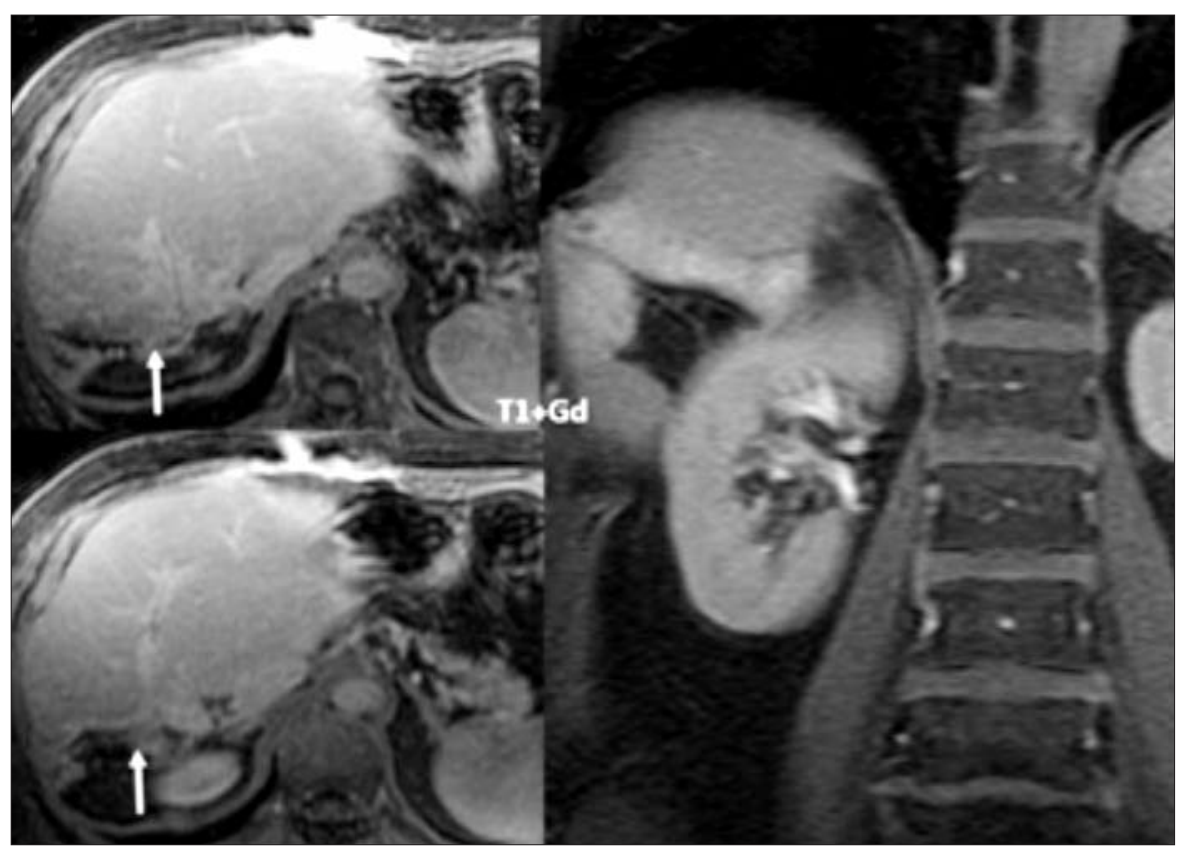


nant transformation into intestinal metaplasia due to the process of chronic inflammation. The small percent of Kulchitsky cells in the biliary ducts might explain the low incidence of this histopathological subtype at the level of the biliary structures $(2-5)$.

When it comes to the most commonly reported symptoms, they usually consist of diffuse abdominal pain, jaundice, pruritus, vomiting and weight loss, the preoperative differential diagnostic with a primary bile duct neoplasm being very difficult to be established (5-7). In order to provide a better characterization of the tumor during the preoperative workup, certain authors have proposed performing percutaneous needle biopsy or endoscopic brush; however, in most cases these methods can only identify the presence of a malignant process, the tumoral subtype being identified only after performing a surgical gesture of resection $(8,9)$.

Neuroendocrine tumors of the biliary tree are uncommon comparative with Klatskin tumors. The histopathological and immunohistochemistry tests are mandatory for the definitive diagnosis and tumoral grading of NETs, on which the oncological management is based. Many biomarkers are useful in immunohistochemistry staining for diagnosing of NETs, such as cytokeratin $\mathrm{C} 7$, synaptophysin, $\alpha 1$ antichymotrypsin, chromogranin A, NeuronSpecific-Enolase and antigen Ki-67. According to the mitotic and $\mathrm{Ki}-67$ indexes, the European Neuroendocrine Tumor Society (ENETS) proposed a classification system into three grades (G1-G3): according to this classification, G1 tumors are characterized by less than 2 mitoses/10 high power fields (HPF's) or a Ki67 value less than $2 \%$, G2 tumors present 2-20 mitoses/10 HPF or a Ki67 value between 3 and $20 \%$ while G3 tumors present more than 21 mitoses/10 HPF or a Ki67 index greater than 20\% (10). Poorly differentiated NETs are classed G3 and are known as neuroendocrine carcinomas (NECs). NETs account for $0.2-2 \%$ and NECs for $0.19 \%$ of bile duct tumors (11). Another widely used classification system was the one provided by the World Health Organization (WHO) in 2010 which identified three histopathological subtypes: neuroendocrine tumors which present a mild to moderate nuclear atypia and a low number of mitoses (less than 20/ 10 HPF), neuroendocrine carcinomas which are poorly differentiated, high grade tumors, with increased nuclear atypia and higher than 20 mitoses/10HPF and mixed adenoneuroendocrine carcinomas which contain both gland and neuroendocrine cells and which are also considered as carcinomas (1).

When compared to biliary cholangiocarcinomas NETs are less locally invasive and with only $1 / 3$ of them developing metastases. Surgical radical resection is the main treatment and offers the best chance of cure. The operation depends on the tumor's localization, invasion and presence of distant metastases $(6,7,12-14)$. Operation consists of pancreaticoduodenectomy (tumor located in the distal common bile duct), bile duct resection followed by cholangiojejunostomy (tumor located in the middle CBD) or bile duct resection followed by cholangiojejunostomy associated with partial hepatectomy (proximal tumor with intra-hepatic invasion). Lymph node dissection is advocated. In case of vascular involvement of the hepatic pedicle, an extensive operation with vascular resection and reconstruction could be performed, being justified by a good survival rate of these patients. An effective palliative cytoreduction that removes at least $90 \%$ of the secretory neoplastic tissue is possible but highly increases the postoperative morbidity $(12,13,15-17)$. We presented our case in which an extensive operation was performed for locally extended biliary tumor with portal vein involvement suspicioned on MRI imagining and confirmed during surgical dissection. Intraoperative ultrasound can aid for the assessment of vascular invasion by the biliary tumor.

An interesting study investigating the role of surgery in patients with biliary neuroendocrine tumors as well as the main prognostic factors was conducted by Kim et al. and was published in the journal Digestive and Liver Disease in 2011 (18). The study included 20 patients submitted to surgery 
with curative intent, between 2000 and 2010 . According to the location of the tumor, seven cases were diagnosed with gallbladder lesions, four cases presented bile duct tumors and the remaining nine cases presented ampullary lesions; in that study none of the patients presented intrahepatic bile duct tumors. However, preoperatively, none of the patients presented the suspicion of neuro-endocrine tumors of the biliary tract. When it comes to the type of performed surgical procedure, all patients with gallbladder lesions were submitted to extended cholecystectomy and liver resection while all the four cases with bile duct tumors and eight cases with ampullary lesions were submitted to pancreaticoduodenectomy; the ninth case diagnosed with an ampullary tumor was suitable for surgical ampullectomy. Moreover, 11 patients presented lymph node metastases while four cases presented gallbladder tumors associated liver metastases which were successfully resected; when it comes to the completeness of cytoreduction, 17 patients benefitted from an $\mathrm{R} 0$ resection while the remaining three cases (one case with gallbladder tumor, one case with bile duct tumor and one case with an ampullary tumor) were submitted to an R1 resection. Postoperatively patients presenting an R1 resection, those with locally disseminated disease as well as those with aggressive biological tumors were submitted to 5 -fluorouracil chemotherapy. The authors demonstrated that the primary tumor dimensions, as well as the angiolymphatic and venous invasion were significantly correlated with the degree of differentiation (smaller lesions with limited angiolymphatic and venous spread being significantly associated with a well differentiated tumor). In the meantime, up to two-thirds of patients were diagnosed with neuroendocrine or adenoneuroendocrine carcinomas. When it comes to the long term follow up, $70 \%$ of cases experienced recurrent disease, the initial location of the primary tumor presenting a minimal influence on the risk of relapse $(p=0,313)$; the most common sites of relapse were at the level of the lymph nodes, liver and lungs, the risk of recurrence being significantly influenced by the degree of differentiation. Moreover, the overall survival rate was significantly influenced by the development of recurrent disease, as well as by the histopathological subtype (according to the WHO classification) (18).

However, although techniques of extended hepato-bilio-pancreatic resections have significantly improved in the last decades (19-23), there are still situations in which resection is not feasible; therefore surgery becomes palliative and consists of biliary or digestive derivative interventions or even limited to biopsy through laparotomy or laparoscopy (24).

In other situations local-regional therapies are used such as: chemoembolization, alcoholization, cryosurgery and radiofrequency ablation. The traditional radiotherapy has little use for such tumors; instead targeted radiotherapy with 131 IMIBG is justified by the ability of some NETs to concentrate inside them the radiolabeled analogue.

\section{Conclusion}

Having a very low incidence at the biliary tract, the preoperative diagnosis of biliary NETs is rarely accomplished in the absence of positive specific serum markers. Preoperative and intraoperative imaging exams are important in evaluating the loco-regional tumoral invasion and identifying vascular involvement in the liver pedicle, features that influence the decision and type of the surgical procedure. The HP and IHC exams are the final tools for the diagnosis that guides the postoperative oncological management.

\section{Conflict of Interest}

The authors declare no conflicts of interests.

\section{References}

1. Bosman FT, Carneiro F, Hruban RH, et al. WHO classification of tumours of the digestive system. $4^{\text {th }}$ ed. Lyon: The International 
Agency for Research on Cancer; 2010.

2. Barron-Rodriguez LP, Manivel JC, Mendez-Sanchez N, Jessurun J. Carcinoid tumor of the common bile duct: evidence for its origin in metaplastic endocrine cells. Am J Gastroenterol. 1991; 86:10731076

3. Noronha YS and Raza AS. Well-differentiated neuroendocrine (carcinoid) tumors of the extrahepatic biliary ducts. Arch Pathol Lab Med. 2010;134:1075-1079.

4. Kuwabara $\mathrm{H}$ and Uda $\mathrm{H}$. Small cell carcinoma of the gall-bladder with intestinal metaplastic epithelium. Pathol Int. 1998;48:303-306.

5. Khan FA, Stevens-Chase A, Chaudhry R, Hashmi A, Edelman D, Weaver D. Extrahepatic biliary obstrution secondary to neuroendocrine tumor of the common hepatic duct. Int J Surg Case Rep. 2017;30:46-49.

6. Tsalis K, Vrakas G, Geroukis T, Cheva A, Roidos GN and Lazarides C. Primary neuroendocrine tumor of the extrahepatic biliary tree mimicking Klatskin tumor. J Gastrointestin Liver Dis. 2010;19: 341-342.

7. Senthil Kumar MP, Marudanayagam R. Klatskin-like lesions. HPB Surg. 2012;2012:107519.

8. Kassir R, Lointier P, Breton C, Blanc P. Postoperative finding of gastric neuroendocrine tumor in a patient undergoing a mini gastric bypass: points to consider. Surg Obes Relat Dis. 2014;10: 1009-1011.

9. Navaneethan U, Njei B, Lourdusamy V, Konjeti R, Vargo JJ, Parsi MA: Comparative effectiveness of biliary brush cytology and intraductal biopsy for detection of malignant biliary strictures: a systematic review and meta-analysis. Gastrointest Endosc. 2015 81:168-176.

10. Kim JY, Hong SM. Recent Updates on Neuroendocrine Tumors From the Gastrointestinal and Pancreatobiliary Tracts. Arch Pathol Lab Med. 2016;140:437-448.

11. Oshiro $\mathrm{Y}$, Gen R, Hashimoto S, Oda T, Sato T and Ohkohchi N. Neuroendocrine carcinoma of the extrahepatic bile duct: A case report. World J Gastroenterol. 2016;22:6960-6964.

12. Bhandarwar AH, Shaikh TA, Borisa AD, Palep JH, Patil AS, Manke AA. Primary neuroendocrine tumor of the left hepatic duct: a case report with review of the literature. Case Rep Surg. 2012; 2012:786432.

13. Hoepfner L, White JA. Primary extrahepatic bile duct neuroendocrine tumor with obstructive jaundice masquerading as a
Klatskin tumor. J Surg Case Rep. 2017;2017:rjx104.

14. Quartey B: Primary Hepatic Neuroendocrine Tumor: What Do We Know Now? World J Oncol 2: 209-216, 2011.

15. Liu Z, Zhang DY, Lu Z, Zhang P, Sun WL, Ma X, Wu H, Wu BQ and Zhou S. Neuroendocrine tumor of the common bile duct: a case report and review of the literature. Onco Targets Ther. 2018;11: 2295-2301.

16. Raspanti C, Falco N, Silvestri V, Rotolo G, Bonventre S, Gulotta G. Neuroendocrine tumor of the common bile duct: case report. $G$ Chir. 2016;37:275-280.

17. Abe $T$, Nirei $A$, Suzuki $N$, Todate $Y$, Azami $A$, Waragai $M$, et al. Neuroendocrine tumor of the extrahepatic bile duct: A case report. Int J Surg Case Rep. 2017;40:6-9.

18. Kim J, Lee WJ, Lee SH, Lee KB, Ryu JK, Kim YT, et al. Clinical features of 20 patients with curatively resected biliary neuroendocrine tumours. Dig Liver Dis. 2011;43:965-970.

19. Bacalbasa N, Brezean I, Anghel C, Barbu I, Pautov M, Balescu I, et al. Management of a Fulminant Upper Gastrointestinal Bleeding Exteriorized Through Hemobilia Due to Arteriobiliary Fistula Between the Common Bile Duct and a Right Hepatic Artery Aneurysm - A Case Report. In Vivo. 2017:31:983-989.

20. Bacalbasa N, Brezean I, Anghel C, Barbu I, Pautov M, Balescu I, et al. Successful Resection and Vascular Ligation of a Large Hepatic Artery Aneurysm - A Case Report and Literature Review. In Vivo. 2017;31:979-982.

21. Bacalbasa N, Balescu I. Infracolic Approach to the Superior Mesenteric Vessels for a Large Pancreatic Tumor with Right Colon Invasion - A Case Report and Literature Review. Anticancer Res. 2017;37:2609-2613.

22. Bacalbasa N, Balescu I, Dima S, Brasoveanu V, Popescu I. Pancreatic Resection as Part of Cytoreductive Surgery in Advanced-stage and Recurrent Epithelial Ovarian Cancer -- A Single-center Experience. Anticancer Res. 2015;35:4125-4129.

23. Brasoveanu V, Anghel C, Barbu I, Pautov M, Ionescu MI, Motthor $\mathrm{M}$, et al. Pancreatoduodenectomy en bloc with portal and superior mesenteric artery resection--a case report and literature review. Anticancer Res. 2015;35:1613-1618.

24. Hwa J, Chung DJ, Hahn ST, Lee JM. Imaging findings of neuroendocrine neoplasm in biliary duct with liver metastasis. J Korean Soc Radiol. 2013;69(3):207-211. 